\title{
Lex Actualization on Describing of Military Acts, Processes and States
}

\section{Актуалізація лексем на позначення військових дій, процесів та станів}

\section{Maryna Navalna}

Dr. in Philology,

Professor
Марина Навальна

доктор філологічних наук, професор

E-mail: mnavalna@gmail.com

orcid.org/0000-0002-5064-3122

\section{Yuliia Kaluzhynska}

Ph.D. in Philology, Lecturer
Юлія Калужинська

кандидат філологічних наук, викладач

\section{E-mail: kaluzhynskaya@gmail.com orcid.org/0000-0002-9787-2686}

Pereiaslav-Khmelnytskyi

Hryhorii Skovoroda State

Pedagogical University

30, Sukhomlynskyi Str.,

Pereiaslav-Khmelnytskyi,

Kyiv Region, Ukraine, 08401
ДВНЗ «Переяслав-

Хмельницький державний педагогічний університет імені Григорія Сковороди»

$\triangle$ вул. Сковороди, 30,

м. Переяслав-Хмельницький, Київська обл., Україна, 08401

Original manuscript received March 12, 2018

Revised manuscript accepted October 13, 2018

\section{ABSTRACT}

The article describes the most commonly used lexemes from the texts of contemporary Ukrainian periodicals, reveals new lexical units, expands the scope of the operation of lexemes on military topics in the media materials of socio-political, military and other issues; the functional-stylistic role of military 
vocabulary in the language of the press is determined and emphasized on a negative evaluation in journalistic materials.

In the article for the study of military vocabulary in the language of Ukrainian periodicals at the beginning of the XXI century observation and descriptive methods are used. At different stages of the study, the method of functional analysis was used to determine the stylistic load of lexical units.

It is concluded that due to a number of extra-linguistic factors of socio-political orientation, the modern Ukrainian language was enriched with new tokens of military actions, processes and states, which is reflected in the pages of the national press of the second decade of the XXI century. In particular: the level of development of science and technology in the language environment, socio-political conditions in the linguistic society, the state language (terminology) policy in society, the functional status of the state language, the international status of the national language.

The military vocabulary is singled out into two groups: 1) the one that names persons; 2) the one that characterizes processes, actions and states. According to our observations, the most significant manifestations are lexemes of foreign origin for the nomination of persons. Quite often, military vocabulary has a negative coloring, contrasts with the neutral vocabulary and attracts the attention of the reader.

The military vocabulary is still a little explored layer of lexicology and requires a thorough study, in particular, the question of replenishment of thematic groups, word-building potential of lexemes, etc.

Key words: military vocabulary, extralinguistic factors, language means of manipulation, stylistic role, sphere of use, emotional and expressive coloring.

\section{Вступ}

У зв'язку 3 подіями в нашій державі (анексія Російською Федерацією Криму, вторгнення російських військ на територію України, проведення АТО (антитерористичної операції) в Донецькій та Луганській областях та військові дії на сході нашої держави) у публіцистичних текстах другого десятиліття XXI ст. активізовано військову лексику. Журналісти послуговуються нею як для відображення військового життя українських солдатів, так для висвітлення суспільно-політичних процесів у країні.

У сучасній психолінгвістиці, соціолінгвістиці, соціальних комунікаціях існує чимало розвідок науковців, присвячених уживанню військової лексики на прикладі творів українських письменників із погляду їхньої стилістичної ролі чи українських писемних пам'яток, 
що дає можливість простежити історію виникнення військових термінів. Проте нині практично немає наукових праць, у яких би йшлося про використання військової лексики в мові преси. Через уплив позамовних чинників у текстах української періодики значно активізовано військову лексику. Одна 3 головних проблем мови засобів масової інформації полягає в тому, що нелінгвістичні елементи тексту повідомлення в пресі чи на телебаченні (або на радіо) завжди змінюють структуру та зміст лексем, словосполучень, речень, абзаців тощо. Таким чином, екстралінгвістична інформація впливає на суто лінгвістичну (Холод, 2003). Тому вважаємо, що питанню функціонування та впливу військової лексики на мовну практику потрібно приділити більше уваги, визначити іiі вплив на свідомість споживачів інформації.

За визначенням Л.В. Туровської, те, що в процесі формування української військової термінології чітко простежено періоди розвитку, пов'язане з конкретними суспільно-політичними умовами ii формування. За походженням дослідниця виокремлює такі групи військових термінів: 1) власномовні («внутрішньомовні») запозичення: а) народні назви або переосмислення загальновживаних слів; б) спільнослов'янські назви; в) перші іншомовні запозичення; 2) давні іншомовні запозичення; 3) запозичення XVIII-XIX ст.; 4) нові іншомовні запозичення (Туровська, 2007: 83).

Дослідниця 3.О. Дубинець серед військової лексики розрізняє: 1) назви осіб, пов’язаних з військовою справою; 2) назви зброї, військового спорядження й регалій; 3) назви збройних сил, військових одиниць, стратегії або тактики бойових дій та їх наслідків (Дубинець, 2015: 169). Основною функцією військового терміна є номінативно-дефінітивна, тобто називання та визначення спеціального поняття (Байло, 2013: 64).

Як стверджує Л.В. Туровська, на розвиток військової субмови мають уплив лише екстралінгвальні чинники, серед яких називає виробничо-технологічний (соціально-економічний), соціально-комунікативний (естетичний, інтелектуальний), історико-політичний чинники (Туровська, 2007: 35). На думку I.O. Литовченко, у результаті використання досягнень науковотехнічного прогресу відбувся якісний стрибок у розвитку засобів військової боротьби, який назвали військово-технічною революцією. На появу та розвиток військових термінів упливають такі позамовні 
чинники: рівень розвитку науки й техніки в мовному середовищі, соціально-політичні умови в лінгвістичному соціумі, державна мовна (термінологічна) політика в суспільстві, функціональний статус державної мови, міжнародний статус національної мови (Литовченко, 2014: 77-78).

Варто звернути увагу в контексті військової лексики на питанні впливу на читача, на виникненні негативних емоцій у споживачів інформації, що й маніпулює свідомістю читачів. У зв'язку з цим питання впливу, маніпуляції на будь-якому рівні (особливо на лексичному) набувають особливого значення. Маніпуляція вивчається в межах психології, соціології, політології, філософії, лінгвістичних робіт 3 маніпулювання реципієнтом існує не так багато (Баскова, 2006; Катенева, 2010; Косенко, 2008; Шиллер, 1980; Clayman \& Loeb, 2018; Diakidoy, 2015). Маніпуляція свідомістю цільової аудиторії ефективно здійснюється у публікаціях, що присвячені економіці, культурі, дозвіллю. Реципієнт рідше виявляє факт маніпуляції, бо не шукає в них підоснови і тому менш критично сприймає такі тексти. Однією з умов успішної маніпуляції $€$ iї непомітність, коли реципієнт «вірить, що все, що відбувається, $€$ природним та неминучим» (Шиллер, 1980: 43). У такому випадку в нагоді можуть стати евфемізми - слова або вислови, що здатні вуалювати, затемнювати факти, які можуть викликати антипатію або негативну оцінку з боку суспільства. Як зазначає Ю.С. Баскова (Баскова, 2006), евфемізми володіють високим маніпулятивним потенціалом за рахунок непомітності для реципієнта, оскільки в сучасному інформаційному потоці їх важко вичленити з контексту та ідентифікувати табуйований денотат, що ховається за евфемізмом. Серед інших лексичних засобів, що активно застосовуються задля маніпулятивного впливу, можна виділити полісеманти, омоніми, оказіоналізми. Останні за рахунок своєї нестандартності створюють експресивність матеріалу, розстановку акцентів. Зіштовхуючи значення омонімів, журналіст привертає увагу читача за рахунок каламбурів і актуалізує в публікації додаткові сенси (Катенева, 2010).

Про роль засобів масової інформації у формуванні парадигми психолінгвістичного інструментарію дослідники зауважують при іміджуванні політиків, при виборчому процесі (Холод, 2003), сьогодні можна стверджувати про відповідний інструментарій при військовому конфлікті на сході України. 


\section{Методи дослідження}

У статті для вивчення військової лексики в мові української періодики початку XXI ст. використано як основні метод спостереження та метод контент-аналізу, а також метод інтроспекції як спостереження над образами, що виникають у нашій свідомості, коли ми чуємо військові слова. На різних етапах дослідження послуговувалися методом функціонального аналізу для визначення стилістичного навантаження лексичних одиниць.

\section{Результати дослідження}

Останні декілька років наша країна перебуває у стані офіційно невизнаної війни - військовому конфлікті на сході держави. Цю тему активно обговорюють у засобах масової інформації, і в газетах зокрема. Ми умовно об'єднали військову лексику у кілька груп: 1) та, що називає осіб; 2) та, що характеризує процеси, дії та стани. За нашими спостереженнями, найбільшого вияву набувають лексеми іншомовного походження для номінації осіб, що так чи інакше мають відношення до процесів на території проведення дій АТО. Такі лексеми функціонують не тільки в мові засобів масової інформації, але й активно переходять до мовної діяльності споживачів інформації.

В українських газетах натрапляємо на функціонування лексеми мародер «вояк, що грабує вбитих та поранених після бою або мирне населення під час війни» (Бибик, 2006: 356). Вона негативно характеризує тих осіб, що прагнуть нажитись у період війни, напр.: «Також донеччани попереджають один одного, щуо в місті орудують мародери» («Світ», 15.11.2014).

Для позначення сусідньої держави - Російської Федерації журналісти послуговуються лексемою агресор «той, хто налаштований вороже, недоброзичливо, який шкідливо пливає на що-небудь» (Бибик, 2006: 17), напр.: «Хоча, на жаль, це не зупиняє агресора» («Дзеркало тижня», 16.11.2014).

У мові українських газет активно функціонує лексема терорист «той, хто здійснює насильницькі дії з метою залякування, пригнічення політичних суперників, конкурентів» (Бибик, 2006: 534) для позначення осіб, що активно займають позиції на сході України. Пор.: «Терористи вкорінюються в кабінетах» («Голос України», 16.10.2014); «У результаті конфлікт став війною 
украӥнського народу проти путінських терористів» («Газета по-українськи», 14.11.2014).

Лексема сепаратист «той, хто прагне до відокремлення, відособлення, прихильник політичного руху національних меншин, скерованого на відокремлення від державного цілого й утворення самостійної держави» (Бибик, 2006: 489) активно вживають у газетних текстах на військову тематику для позначення осіб, зацікавлених у порушенні державної цілісності України, пор.: «Сепаратисти» просунулись на захід з моменту «припинення вогню» («День», 12.11.2014); «А взагалі ми воюємо не проти сепаратистів» («Україна молода», 12.11.2014).

Для позначення нечесних військових вжито лексему диверсант «шкідник, особа, що здійснює диверсію, ламає, підпалює, підриває військові, промислові та ін. об’єкти, засоби зв’язку чи іншого державного або суспільного майна» (Бибик, 2006: 177), напр.: «У Запоріжжі затримали диверсанта, який хотів створити щуе одну «народну республіку» («День», 21.11.2014); «Ще двох диверсантів українські вояки знищзили різдвяної ночі у Тольманівському районі Донеччини» («Україна молода», 9.01.2015); «Полторак: Диверсантів більшає, готуються «працуювати»на військових об'єктах» («День», 21.04.2015). У цій же тематиці функціонують й складні слова, пор.: «Учора на Луганщчині «заблукала» група російських розвідниківдиверсантів» («Україна молода», 5.12.2014).

Найактивнішого вияву в газетних текстах набуває лексема окупант «той, що здійснює окупацію» (Бибик, 2006: 399), пор.: «Поліг, прикриваючи від російських окупантів бойових побратимів» («Високий Замок», 12.11.2014); «Нічого святого: бойовики та окупанти не припиняли вбивати навіть у дні одного з найбільших свят» («Україна молода», 9.01.2015); «..воӥни украӥнської армї втримали краӥну від тотального захоплення російським окупантом» («Високий Замок», 8.01.2015).

Лексема бойовик «учасник якої-небудь бойової групи, загону» (СУМ, 1970-1980, I: 213) використовується для характеристики російських військових, напр.: «За добу бойовики здійснили 13 збройних провокаиій, втрат немає...» («Голос України», 18.12.2014); «Кіборги» зачистили від бойовиків новий термінал Донецьького аеропорту» («Високий Замок», 2.11.2014); «Бойовики 
продовжують наступ» («День», 02.02.2015); «Штаб: бойовики планують провокацію, хочуть зірвати «тишу» («День», 15.03.2015).

Для позначення особливо жорстоких військових журналісти послуговуються лексемою головоріз «бандит, убивця» (СУМ, 1970-1980, II: 113), напр.: «...а ти знаєш, щьо Харків охороняють 4 батальйони головорізів» («День», 16.01.2015).

Осіб, що беруть участь у діях на сході нашої крани, номінують ще лексемою найманець. За «Словником української мови» вона тлумачиться як «1. Той, хто найнявся на роботу до приватного власника, підприємця; 2. Солдат або офіцер найманої армії, наємник; 3. Той, хто захищає чужі інтереси не з переконання, а 3 корисливих мотивів» (СУМ, 1970-1980, V: 96), пор.: «С й найманці з інших країн» («Україна молода», 05.12.2014).

Таким чином, лексеми на позначення осіб, які беруть участь у конфлікті на сході України і воюють на боці ворожих сил, викликають у споживачів інформації негативні емоції, відіграють значну роль у формуванні парадигми психолінгвістичного інструментарію.

Активного вияву в текстах на військову тематику набувають жаргонні одиниці, що номінують стани, зокрема: під кайфом «бути у стані наркотичного сп'яніння» (Ставицька, 2005: 348); та осіб: відморозок «1. Емоційно та інтелектуально недалека людина, часто агресивна; 2. Людина, позбавлена моральних принципів; 3. Член угрупування рекетирів, який бере участь у бойових операціях» (Ставицька, 2005: 87), напр.: «Бойовики під кайфом» («Сільські вісті», 17.04.2015); «Хоча «відморозків» серед ополченців багато, десь відсотків 10 - констатує журналіст» («День», 16.01.2015); «Бараки з рабами цілодобово охороняли місиеві «відморозки» 3 вівчарками» («Високий Замок», 09.11.2014).

У текстах на військову тематику натрапляємо на лексеми, що не мають тлумачення в словниках, та 3 огляду на сферу застосування їх можна кваліфікувати як жаргонні: сnец «те саме, що й спеціаліст», сепари «сепаратисти», напр.: «Російські «специ» зайнялися «Новоросією»: пронумерували банди» («Газета по-українськи», 16.01.2015); «Так от, «сепари» подзвонили $i$ сказали - мінясмо зараз на нашого або пристрелити, бо глюкоза дорога» («День», 17.02.2016); «Сепари» $i$ росіяни почали шалений обстріл «коридору» («Високий Замок, 12.11.2014). 
Функціонування новотворів у військовій тематиці надає текстам емоційного забарвлення. Наприклад, для номінації осіб, які є прихильниками змін на сході України і підтримують діяльність бойовиків, використовують лексеми вата та ватяний. Це семантичні неолексеми, що з'явились разом із початком бойових дій на Донбасі та позначають збірний образ твердолобого російського прихильника, фанатично відданого ідеї «Русского мира» (http://www.bbc.com/ukrainian/ukraine_in_russian/2014/08/140808 ru_s_new_words). Таким чином використання подібних лексичних одиниць надає текстам яскравої негативної оцінки, пор.: «Попри чималу кількість сепаратистів $i$ «вати», місто є кому захистити, кажуть патріотично налаштовані харків'яни» («Високий Замок», 16.04.2015); «С чимало фактів, коли «ватяні» викладачі все щуе залишаються на своїх місиях роботи» («Сільські вісті», 06.10.2015).

Саме такі психолінгвістичні інструменти як: маркованість, емоційність, наявність широкої семантики в жаргонізмах створюють особливу картину конфліктної ситуації на Донбасі.

Характерним для статей на цю тематику $є$ використання авторських неологізмів, утворених основоскладанням: людолови (ті, хто полює на мирне населення Донбасу), людоловки (засоби, що використовуються для вербування місцевого населення). Хоч лексема людолови не є новою за своїм походженням, та вживання іiі щодо процесів на Донбасі надає їй нового значення, пор.: «Облави людоловів» («Сільські вісті», 30.12.2014); «Відбуваєтьсяцинічне примушування та заманювання громадян до «людоловок», $а$ як інакше назвати місияя для псевдоголосування» («День», 02.11.2014).

Негативне забарвлення має також новотвір ухилянти, котрий характеризує осіб, що уникають військової служби у непростий час для країни, напр.: «Ухилянти» $\epsilon .$. Але ж $\epsilon$ і добровольичі» («Високий замок», 29.01.2015).

Новотвори виділяємо як стилістичний засіб, який здатний певною мірою вуалювати, затемнювати факти, викликати антипатію або негативну оцінку. Такі лексеми мають високий маніпулятивний потенціал за рахунок непомітності для реципієнта, оскільки в сучасному інформаційному потоці їх виділяють із контексту тільки лапки, а денот «прихований».

Лексика, що характеризує військові процеси, теж набула активного вияву в мові сучасних засобів масової інформації. Значна 
ii частина - це слова іншомовного походження, що 3 огляду на сферу їх застосування мають негативний відтінок. Наприклад, лексема диверсія «1. Акт зруйнування або пошкодження об’єктів військового, державного значення агентами ворожих країн або партизанами, підпільниками в тилу окупантів; 2. Військова операція, здійснювана для відвернення уваги противника від місця, де готується головний удар; 3. Підривана діяльність у якій-небудь сфері державного устрою» (Бибик, 2006: 177) часто вживається для позначення певних дій на окупованих територіях східної України, напр.: «Фірташ став інструментом політико-економічних диверсій, спрямованих проти України» («Урядовий кур'єр», 18.12.2014); «Через диверсію на блокпосту на Луганшуині один військовий загинув $i$ троє поранено» («Голос України», 17.01.2015); «Сили ATO попередили диверсію терористів біля Новотошківки» («Газета по-українськи», 20.04.2015); «Подї у Сватовому скидаються на диверсію» («Урядовий кур'єр», 31.10.2015).

Через події, що відбуваються на Донбасі, у мові мас-медіа активно функціонують лексеми тероризм «1. Здійснювання, застосовування терору, діяльність i тактика терористів; 2. Повідомлення з метою залякування про можливий терористичний акт» (Бибик, 2006: 534) та екстремізм «прихильність до крайніх поглядів і заходів» (Бибик, 2006: 207), напр.: «Україна закликає світ об'єднати зусилля в боротьбі $з$ тероризмом» («Високий Замок», 8.01.2015); «..він підкреслив, щзо необхідно боротися 3 тероризмом, екстремізмом $i$ організованою злочинністю» («Високий Замок», 9.01.2015).

Вживання лексеми дезертирство («залишення без дозволу військовослужбовцем місця служби; нехтування своїми громадськими або службовими обов'язками» (Бибик, 2006: 162)) та дезертир (військовослужбовець, котрий залишив без дозволу місце служби) теж вказує на відповідні процеси в зоні проведення АТО, напр.: «...y изілій низиі терористичних формувань «ДНР» набирають масового характеру випадки дезертирства» («Україна молода», 28.11.2014); «Пізніше стало відомо, щзо дезертира затримали неподалік від місия подї̈» («Сільські вісті», 16.09.2016).

Запозичена лексика використовується насамперед для найменування явищ i процесів, що раніше не мали місце або не були характерними для українського простору, тому 3 появою або 
поширенням відповідних явищ виникла потреба їх використання в мовній практиці українців, що у свою чергу, наводить на думку про функціональність психолінгвістичного інструменту, який пропонує мова мас-медіа.

Вживання в текстах на військову тематику розмовної лексики надає їм експресивного характеру та підкреслює негативні дії. Напр., лексема гатити «розм. Стріляти по кому-, чому-небудь, в когось, щось» (СУМ, 1970-1980, II: 41) негативно характеризує процес, пов'язаний із перебуванням бойовиків на територіях Східної України, напр.: «Напередодні ворог 47 разів гатив по опорних пунктах наших військ» («Сільскі вісті», 4.03.2016); «АТО: бойовики гатять із танків та мінометів» («Високий Замок», 11.03.2016); «Терористи активно гатять із «градів» на Донеччині, на Луганщині - «затишия» («День», 19.04.2015).

Лексему чубитися - «розм. Битися, хапаючи один одного за чуб; перен. не мирити між собою» (СУМ, 1970-1980, XI : 371) - 3 переносним значенням вживають не лише для номінації непорозумінь між владними діячами, а й для позначення процесу непорозуміння між бойовиками пор.: «На Луганшзині чубляться бойовики: 23 знищили» («День», 4.01.2015).

Розмовні слова надають доступності інформації читачам, підкреслюють правдивість фактів. Між стандартом літературної мови в газетній статті та емоціями й експресією, що надають розмовні елементи, виникає контраст. Такий контраст-конфлікт провокує читача до віри в «правду» викладеного матеріалу. Часто автори зумисне застосовують такий конфлікт-контраст. За суттю цей конфлікт стилів є прагматичною ознакою вербального повідомлення в газеті (Сасіорро, 1999)

Із негативною оцінкою вжито лексеми, що безпосередньо описують воєнні дії: обстріл «тривала стрільба по якій-небудь цілі» (СУМ, 1970-1980, V: 586); вибух «розрив вибухової речовини, спеціального снаряда, оболонки чого-небудь» (СУМ, 1970-1980, I: 358); загинути «умирати, гинути, зазвичай передчасно» (СУМ, 1970-1980, III: 75); тортури «фізичне насильство, катування під час допиту обвинуваченого, щоб домогтися від нього зізнання» (СУМ, 1970-1980, Х: 709), пор.: «Найбільш інтенсивні обстріли відзначені в Донецькому аеропорту» («Високий Замок», 7.01.2015); «У Донецьку лунають вибухи $і$ залпи» («Світ», 10.01.2015); «Пекло 
в Горлівиі: колона танків $і$ вибухи в цеентрі міста» («Світ», 16.01.2015); «Найрезонансніші подї дня в Донбасі: вибухи в Донецьку і нові жертви» («День», 09.02.2015); «Під час итурму Вуглегірська загинули 4 бійців, Семенченка контузило» («Газета поукраїнськи», 1.02.2015); «Бойовики застосовують до людей широкий спектр катувань $i$ тортур» («Газета по-українськи», 17.01.2015); «Командир роти «Крим»: Тортури для Росіі буденність» («Газета поукраїнськи», 18.12.2014).

Для опису деяких процесів у текстах на військову тематику використовують лексеми 3 переносним значенням: бойня («спеціально устатковане приміщення для забою худоби, різниця; перен. масове вбивство людей, бійня, різанина» (СУМ, 1970-1980, I: 212)); а також такі, що не мають зафіксованого переносного значення у лексикографічних джерелах: юшити «литися, текти у великій кількості» (СУМ, 1970-1980, ХI: 617), вигравати «Здобувати, одержувати що-небудь завдяки певній грі, при розігруванні лотереї і т. ін; Добиватися перемоги, позитивного результату в чому-небудь» (СУМ, 1970-1980, I: 378), закон «встановлене найвищим органом державної влади загальнообов'язкове правило, яке має найвищу юридичну силу» (СУМ, 1970-1980, III: 154). Напр.: «Україна в иій бойні може мати дуже відчутні втрати» («Газета по-українськи», 14.11.2014); «3а його словами, о 2:43 ночі в місті «юшила» артилерія» («День», 16.01.2015); «За два місяиі бойовики «виграли» частину територій Донбасу - ОБСЄ» («Газета по-українськи», 12.11.2014); «Події на Донбасі: провокаиії, тортури $i$ «закони» бойовиків» («День», 12.11.2014).

Уважаємо, що лексичні одиниці закон та вигравати в контексті про військові дії на сході України, вжиті в переносному значенні, адже мають інше тлумачення: «отримати щось незаконно» та «порядки, визнані лише бойовиками» відповідно.

У публікаціях на воєнну тематику активно фігурують лексеми 3 переносним значенням на позначення дій та процесів, що набувають нових виявів: накачувати «наповнювати що-небудь рідиною, повітрям i т. ін. за допомогою насоса або іншого приладу; перен., розм. Посилено прищеплювати кому-небудь певні думки, переконання і т. ін» (СУМ, 1970-1980, V: 101); малювати «зображувати кого-, що-небудь на площині олівцем, пером, фарбами тощо; перен. Зображувати словами; описувати; перен. Викликати в 
уяві, свідомості певні образи, картини» (СУМ, 1970-1980, IV: 612), напр.: «Тоді як Росія продовжуе «накачувати» регіон військовою технікою та найманцями, які маскуються під місцевих» («Україна молода», 05.11.2014); «СБУ перехопила, як у ДНР «малюють» результати виборів» («Високий Замок», 03.11.2014).

У контексті дій Російської Федерації щодо східного регіону нашої держави, лексема накачувати вжита в значенні «наповнювати щось, збільшувати кількість чогось». Щодо проблеми виборів на сході України, то вживаючи слово малювати, журналісти вкладають у нього зовсім інший зміст. Мова тут йде про нечесні та непрозорі вибори, що проводились у ДНР і таким чином маємо значення «підробка результатів виборів».

Використана лексема ввічливий взагалі не має зафіксованого переносного значення у лексикографічних джерелах, проте у деяких журналістських текстах його набуває, напр.: «Росія, мовляв, обов'язково скористається ініціативою, щцоб узаконити свою «ввічливу» присутність на Донбасі» («Високий Замок», 19.02.2015). Підкреслено вживання поданої лексеми в переносному значенні й лапками. Таким чином, окрім відомого значення «який дотримується правил пристойності, виявляє уважність, пристойність» (СУМ, 19701980, I: 304), тлумачиться як «який чинить щось без згоди інших».

Маємо кореляцію між функціональним різновидом мовлення та відповідним мовним засобом, що використовуються 3 маніпуляційною метою. У публіцистичних текстах до них належать експресивні одиниці та метафоричність. Таким чином багатозначність лексики - невичерпне джерело оновлення значень слів, незвичайного, несподіваного їх переосмислення, переносні значення надають журналістським текстам розмовності, емоційності, подекуди експресії (Imbir, 2016).

У текстах на військову тематику активного вияву набувають жаргонні дієслова на позначення певних дій: злити «1. Продати щось; 2. Передати комусь певну інформацію» (Ставицька, 2005: 1580 ; відмазатися «виправдатися, зняти 3 себе звинувачення (як правило, заплативши гроші); ухилятися від якоїсь роботи» (Ставицька, 2005: 860; накрити «виявити когось» (Ставицька, 2005: 231), напр.: «ОБСС злила росіянам розташування українських позищій» («Високий Замок», 11.11.2014); «На Донбасі лісник «зливав» інформацію бойовикам» («День», 16.07.2015); 
«Російські офічери «злили» Украӥні дані про військових-зрадників y Криму» («Газета по-українськи», 18.02.2015); «Розповів, щзо його підрозділ на 70\% складається з тих, хто взяв у руки зброю аби «відмазатись» від зони» («День», 04.02.2015); «У Луганській області поновили обстріли - Попасну двічі «накрили» з мінометів» («Світ», 23.02.2015).

Характерним також $є$ використання лексем, що не мають спеціального пояснення в словниках, але можуть бути кваліфіковані як жаргонізми: віджимати «отримувати щось насильницьким шляхом», напр.: «Бойовики «віджимають» у жителів Донбасу будинки $і$ виганяють їх в Україну» («Високий Замок», 5.05.15); «Зараз тут знаходиться «полічія ДНР», на стоянияі стоять «віджаті» відомчі автомобілі...» («Світ», 6.05.15); «Російський офічер на Донбасі торгує «віджатими» у місиевих жителів маиинами» («День», 08.06.2016).

Уважаємо, що маніпулюють свідомістю читачів i за допомогою військової лексики, особливо жаргонізмами, коли однією лексемою передається широка семантика предмета, явища, дії чи процесу. Особливо широку семантику мають дієслова, які активно використовують для маніпулювання свідомістю читачів.

Особливої уваги в публікаціях на воєнну тематику заслуговують складні слова, зокрема найуживаніше серед них гумконвой. Ця лексема складена 3 двох частин: гуманітарний «скерований до бідних людей, потерпілих від стихійного лиха тощо» (Бибик, 2005: 155) та конвой «група озброєних людей, що супроводять кого, що-небудь для охороно або запобігання втечі, варта» (СУМ, 1970-1980, IV: 257). Друга частина надає слову негативного забарвлення, а також тому, що саме цією лексемою номінують так звану гуманітарну допомогу жителям Донбасу від Російської Федерації, під якою насправді маскують одиниці зброї, напр.: «Але партія війни не дрімає. I відправка чергового гумконвою (пропагандисти навіть не приховують, щуо ще воєнторг) може бути пов'язана з ї̈ спробами переламати ситуацію на свій бік» («Високий Замок», 29.10.2014), «Черговий гумконвой РФ готується вторгнутися в Украӥну» («Світ», 20.09.2016); «У Росії відправили черговий гумконвой для окупованих територій Донецької та Луганської областей» («Дзеркало тижня», 20.08.2016); «Росія направила на Донбас 53 «гумконвой» («Слово», 23.06.2016); 
«Путінський «гумконвой» привіз у Донецьк зброю й боєприпаси Розвідка» («Україна молода», 22.02.2016).

Таким чином, серед основних ознак газетного мовлення можна назвати відносну скороченість текстів, деяку телеграфність стилю повідомлень, але 3 наявністю конотованих одиниць мови. Лаконічність та простота синтаксичних побудов у тексті надають інформації характеру протоколу. I текст «наближається» до читача, стає зовсім близьким, тобто ефективним і переконливим.

\section{Висновки}

Через низку позамовних чинників суспільно-політичного спрямування мовна практика збагатилася новими лексемами військових дій, процесів та станів, що відображено на сторінках вітчизняної преси другого десятиліття XXI ст. Ми виділили військову лексику у дві групи: 1) та, що називає осіб; 2) та, що характеризує процеси, дії та стани.

За нашими спостереженнями, найбільшого вияву набувають лексеми іншомовного походження для номінації осіб. Нерідко військова лексика має негативнооцінне забарвлення, контрастує 3 нейтральною лексикою і привертає увагу читача. Викликаючи ті чи ті емоції, автори таким чином маніпулюють свідомістю читачів.

Військова лексика $є$ ще малодослідженим пластом у різних галузях знань та потребує докладного вивчення, зокрема, питання поповнення тематичних груп, словотвірний потенціал лексем, окремого дослідження потребує питання впливу на споживачів інформації, зокрема в різних регіонах України тощо.

\section{Література}

Байло Ю.В. Особливості поняття «військовий термін» (семантичний аспект). Наукові записки Ніжинського державного університету ім. Миколи Гоголя. 2013. Кн. 3. С. $62-65$.

Баскова Ю.С. Эвфемизмы как средство манипулирования в языке СМИ: на материале русского и английского языков : дисс. ... канд. филол. наук : 10.02.19. Краснодар. 2006. 162 с.

Бибик С.П. Словник іншомовних слів: тлумачення, словотворення та слововживання. Харків : ФОЛІО, 2006. 623 с.

Дубинець 3.О. Військова лексика в романі Р. Іваничука «Мальви». Вісник Харківського наиіонального університету імені В.Н. Каразіна. 2015. Вип. 73. C. $169-172$.

Катенева И.Г. Механизмы и языковые средства манипуляции в текстах СМИ : дисс. ... канд. филол. наук : 10.02.01. Новосибирск. 2010. 250 с. 
Актуалізація лексем на позначення військових дій, процесів...

Косенко О.П. Структурно-семантические особенности текстов медийного дискурса. Культура народов Причерноморья. 2008. № 142. Т. 1. С. 386-389.

Литовченко І.О. УПлив екстра- та інтралінгвальних чинників на розвиток військової лексики української мови. Науковий вісник Криворізького державного педагогічного університету: Філологічні студіï. 2014. Вип. 10. C. $75-83$.

Словник української мови : в 11-ти т. Київ : Наукова думка, 1970. 1980.

Ставицька Л.О. Український жаргон : словник. Київ : Критика, 2005. 494 с.

Туровська Л.В. Дещо про генезис сучасної української військової термінології. Наукові праці. 2007. Вип. 54. С. 79-84.

Холод О.М. Імідж: мовлення політиків: монографія: в 2 ч. Київ: Київський національний університет імені Тараса Шевченка, 2003. Ч. 2. 259 с.

Шиллер Г. Манипуляторы сознанием: пер. с англ. Москва : Мысль, 1980. 326 с.

Cacioppo, J.T., \& Gardner, W.L. (1999). Emotion. Annual Review of Psychology, 50(1), 191-214. doi: 10.1146/annurev.psych.50.1.191

Diakidoy, I.N., Christodoulou, S.A., Floros, G., Iordanou, K., \& Kargopoulos, P.V. (2015). Forming a belief: The contribution of comprehension to the evaluation and persuasive impact of argumentative text. British Journal of Educational Psychology, 85, 300-315. doi: 10.1111/bjep.12074

Imbir, K. (2016). From heart to mind and back again. A duality of emotion overview on emotion-cognition interactions. New Ideas in Psychology, 43, 39-49. doi: 10.1016/j.newideapsych.2016.04.001

Clayman, S.E., \& Loeb, L. (2018). Polar Questions, Response Preference, and the Tasks of Political Positioning in Journalism. Research on Language and Social Interaction, 51, 127-144.

\section{References}

Bailo, Yu.V. (2006). Osoblyvosti poniattia «viiskovyi termin» (semantychnyiaspekt) [Features of the term «military term» (semantic aspect)]. Naukovi zapysky Scientific Notes, 3, 62-65 [in Ukrainian].

Baskova, Yu.S. (2006). Evfemizmy kak sredstvo manipulirovaniia v yazyke SMI: na material russkoho $\mathrm{i}$ anhlyiskoho yazykov [Euphemisms as a means of manipulation in the language of the media: on the basis of Russian and English language]. Candidate's Thesis. Krasnodar [in Russian].

Bybyk, S.P. (2006). Slovnyk inshomovnykh sliv: tlumachennia, slovotvorennia ta slovovzhyvannia [The dictionary of foreign words: interpretation, derivation and usage]. Kharkiv: FOLIO [in Ukrainian].

Dubynets, Z.O. (2015). Viiskova leksyka v romani R. Ivanychuka «Malvy» [Military lexis in the novel of R. Ivanchuk «Mallows»]. Visnyk Kharkivskoho natsionalnoho universytetu imeni V.N. Karazina - Bulletin of Kharkiv V.N. Karazin National University, 73, 169-172 [in Ukrainian].

Kateneva, I.H. (2010). Mekhanizmy i yazykovye sredstva manipuliatsyy v tekstakh SMI [Mechanisms and language means of manipulation in the media texts]. Candidate's Thesis. Novosibirsk [in Russian].

Kosenko, O.P. (2008). Strukturno-semantycheskie osobennosti tekstov medyinoho diskursa [Structural and semantic features of the texts of media discourse]. Kultura narodov Prychernomoria - Culture of the nation of the Black Sea Coast, 142, 386-389 [in Russian]. 
Lytovchenko, I.O. (2014). Uplyv ekstra- ta intralinhvalnykh chynnykiv na rozvytok viiskovoi leksyky ukrainskoi movy [Influence of extra and intralingual factors on the development of the military vocabulary of the Ukrainian language]. Filologichni stydii - Philological Studies, 10, 75-83 [in Ukrainian].

Slovnyk ukrayinskoyi movy [Dictionary of Ukrainian language] (1970-1980). (Vols. 11). Kyiv: Scientific thought [in Ukrainian].

Stavytska, L.O. (2005). Ukrainskyi zharhon: slovnyk [Ukrainian slang: dictionary]. Kyiv: Krytyka [in Ukrainian].

Turovska, L.V. (2007). Deshcho pro henezys suchasnoi ukrainskoi viiskovoi terminolohii [Something about the genesis of modern Ukrainian military terminology]. Naukovi praci - Scientific Works, 54, 79-84 [in Ukrainian].

Kholod, O.M. (2003) Imidzh: movlennia politykiv [Image: speaking of politicians]. (Vols. 2). Kyiv: Kyivskyi natsionalnyi universytet imeni Tarasa Shevchenka [in Ukrainian].

Shyller, G. (1980). Manipuliatory soznaniem [Consciousness manipulators]. (Trans). Moscow: Mysl [in Russian].

Cacioppo, J.T., \& Gardner, W.L. (1999). Emotion. Annual Review of Psychology, 50(1), 191-214. doi: 10.1146 /annurev.psych.50.1.191

Diakidoy, I.N., Christodoulou, S.A., Floros, G., Iordanou, K., \& Kargopoulos, P.V. (2015). Forming a belief: The contribution of comprehension to the evaluation and persuasive impact of argumentative text. British Journal of Educational Psychology, 85, 300-315. doi: 10.1111/bjep.12074

Imbir, K. (2016). From heart to mind and back again. A duality of emotion overview on emotion-cognition interactions. New Ideas in Psychology, 43, 39-49. doi: 10.1016/j.newideapsych.2016.04.001

Clayman, S.E., \& Loeb, L. (2018). Polar Questions, Response Preference, and the Tasks of Political Positioning in Journalism. Research on Language and Social Interaction, 51, 127-144.

\section{АНОТАЦІЯ}

У статті схарактеризовано найуживаніші лексеми із текстів сучасних українських періодичних видань, виявлено нові лексичні одиниці, простежено розширення сфери функціонування лексем на воєнну тематику в медійних матеріалах суспільно-політичної, військової та іншої тематик; визначено функціонально-стилістичну роль військової лексики в мові преси, наголошено на негативній оцінці в публіцистичних матеріалах та маніпулятивному аспекті поданої лексики.

у статті для вивчення військової лексики в мові української періодики початку XXI cm. використано як основні метод спостереження ma описовий метод. На різних етапах дослідження послуговувалися методом функціонального аналізу для визначення стилістичного навантаження лексичних одиниць.

Зроблено висновки, що через низку позамовних чинників суспільнополітичного спрямування сучасна українська мова збагатилася новими лексемами військових дій, процесів та станів, що відображено 
на сторінках вітчизняної преси другого десятилітmя $X X I \mathrm{~cm}$. Зокрема: рівень розвитку науки й техніки в мовному середовищі, соціально-політичні умови в лінгвістичному сочіумі, державна мовна (термінологічна) політика в суспільстві, функціональний статус державної мови, міжнародний статус національної мови

Виокремлено військову лексику у дві групи: 1) та, що називає осіб; 2) та, що характеризує процеси, дії та стани. За нашими спостереженнями, найбільшого вияву набувають лексеми іншомовного походження для номінації осіб. Нерідко військова лексика має негативнооцінне забарвлення, контрастує з нейтральною лексикою $i$ привертає увагу читача.

Військова лексика є ще малодослідженим пластом лексикології ma потребує докладного вивчення, зокрема, питання поповнення тематичних груп, словотвірний потенціал лексем тощо.

Ключові слова: військова лексика, позамовні чинники, мовні засоби маніпуляції, стилістична роль, сорера використання, емочійноекспресивне забарвлення.

Навальная Марина, Калужинская Юлия. Актуализация лексем на обозначение военных действий, процессов и состояний

\section{АННОТАЦИЯ}

В статье охарактеризованы наиболее употребляемые лексемы из текстов современных украинских периодических изданий, выявлены новые лексические единицы, прослеживается расширение сферы функционирования лексем на военную тематику в медийных материалах общественно-политической, военной и другой тематик; определена функционально-стилистическая роль военной лексики в языкепрессы и отмечена отрицательной оценке в публицистических мaтериалах.

В статье для изучениявоенной лексики в языке украинской периодики начала XXI века. использовано в качествеосновных метод наблюдения и описательный метод. На разных этапах исследования пользовались методом функционального анализа для определения стилистической нагрузки лексических единиц.

Сделаны выводы, что по ряду внеязыковых факторов общественнополитического направления современный украинский язык обогатился новыми лексемами военных действий, процессов и состояний, что отражено на страницах отечественной прессы второго десятилетия XXI века. В частности: уровень развития науки и техники в языковой среде, социальнополитические условия в лингвистическом социуме, государственная языковая (терминологическая) политика в обществе, 
функциональный статус государственного языка, международный статус национального языка.

Выделенавоенная лексика в двегруппы: 1) ma, что называет лиц; 2) та, что характеризирует процессы, действия и состояния.

По нашим наблюдениям, активного проявления приобретают лексемы иноязычного происхождения для номинациилии. Нередко военная лексика имеет негативнооценочные окраски, контрастирует с нейтральной лексикой и привлекает внимание читателя. Военная лексика есть малоисследованным пластом в лексикологии и требует детального изучения, в частности, вопрос пополнения тематических групп, словообразовательный потенциал лексем и тому подобное.

Ключевые слова: военная лексика, внеязыковые фракторы, языковые средства манипуляции, стилистическая роль, сфера использования, эмоционально-экспрессивную окраску. 